\title{
Rights, DUTIES AND OBligations OF COUNTER-PARTIES FOLLOWING Default Under Derivative Contracts
}

\author{
SEAN F. COLLINS
}

The arficle discusses the use of derivative contracts as a risk-management tool and the results of terminating such coniracts, including: termination under conditions of insolvency and non-insolvency of a counter-party; the use of collateral security to miligate the risks of contractual obligations that might terminate prematurely; the duty to negotiate in good faith; notice requirements for termination of a derivative contract; and damages/penalties that arise when a contract is terminated prior to completion.
Cel arficle porte sur l'usage de contrals derives comme outil de gestion du risque et les conséquences de la résiliation de tels contrats. Dans ce cadre, l'auteur traite aussi de la resiliation pour cause d'insolvabilité el non insolvabllité de l'autre partie, de l'usage de garaniles additionnelles pour mitiger les risques des obligations contractuelles pouvant anticiper la résiliation, de l'obligation de négocier de bonne foi, des exigences d'avis dans le cas de la résiliation d'un contrat dérivé ainsi que des dommages intéréts ou de sancions éventuelles dans le cas de la resiliation anticipde du contrat.

\section{TABLE OF CONTENTS}

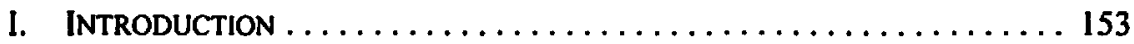

II. Derivative Contracts Generally $\ldots \ldots \ldots \ldots \ldots \ldots \ldots \ldots \ldots \ldots \ldots \ldots$

III. Termination ANd NetTING-OUt Provisions $\ldots \ldots \ldots \ldots \ldots \ldots \ldots$

A. Termination AND NetTING-OUt Generally $\ldots \ldots \ldots \ldots \ldots 156$

B. INSOLVENCY OF A COUNTER-PARTY $\ldots \ldots \ldots \ldots \ldots \ldots \ldots, 156$

C. NON-INSOlVENCY SCENARIOS $\ldots \ldots \ldots \ldots \ldots \ldots \ldots \ldots \ldots$ IS8

IV. Collateral Security $\ldots \ldots \ldots \ldots \ldots \ldots \ldots \ldots \ldots \ldots \ldots \ldots$

A. Third Party Guarantees $\ldots \ldots \ldots \ldots \ldots \ldots \ldots \ldots \ldots \ldots \ldots$

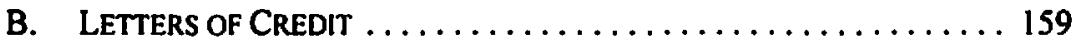

C. Securtty Over Cash and Marketable SeCurities $\ldots \ldots \ldots 160$

V. IS THERE A REQUIREMENT TO PROVIDE REASONABLE

NOTICE OF TERMINATION? ......................... 161

A. InSOLVENCY PROCEEDINGS $\ldots \ldots \ldots \ldots \ldots \ldots \ldots \ldots \ldots \ldots \ldots$

B. NON-InSOLVENCY ProceEdings $\ldots \ldots \ldots \ldots \ldots \ldots \ldots \ldots, 161$

VI. GoOd FAITH REQUIREMENT $\ldots \ldots \ldots \ldots \ldots \ldots \ldots \ldots \ldots \ldots \ldots \ldots \ldots \ldots$

VII. WALK-AWAY PROVISIONS - LIQUIDATED

Damages or PEnalties? ........................ 165

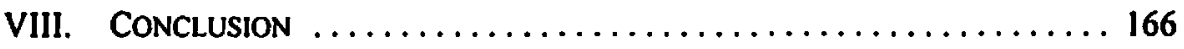

\section{INTRODUCTION}

The use of derivative instruments by oil and gas companies in an attempt to manage the risk attendant with the fluctuation of commodity prices is both an attractive and a relatively

- Partner, McCarthy Tétrault, LLP, Calgary, Alberta. The author gratefully acknowledges the assistance of Larry Robinson, partner in the Calgary office of McCarthy Tétrault LLP, for his valuable guidance and input into this article and the research assistance of Heidi Telstad, Associate, Miller Thomson LLP, Calgary, Alberta. 
commonplace practice. ' Modern day derivative contracts, be they physical delivery contracts, risk-management tools or both, specify the remedies available to the non-defaulting counterparty upon default by a defaulting counter-party. Such remedies generally confer upon the non-defaulting counter-party the ability to terminate the contract in accordance with its terms and to close-out positions. It is clear that such termination provisions are enforceable when a counter-party has availed itself of debtor relief under insolvency protection legislation. What is less clear, however, is the efficacy of such provisions in the event of default for reasons other than insolvency. The issues of whether a non-defaulting counter-party is required to provide reasonable notice of termination upon an event of default arising under a master agreement, the extent to which the good faith doctrine in contractual dealings applies and the enforceability of so-called limited two-way or one-way termination payments recently have been called into question in ongoing proceedings in Alberta.

This article will provide a brief overview of the current state of the law as it relates to the situations involving insolvent counter-parties, together with an overview of the issues involving termination rights in the context of non-insolvency situations.

\title{
II. Derivative Contracts Genfrally
}

While it is beyond the scope of this article to provide a detailed analysis of derivative contracts, ${ }^{2}$ it is nevertheless useful to provide a brief overview of their fundamental characteristics. One commentator, in an attempt to provide a rudimentary explanation of what a derivative contract is, wrote:

\begin{abstract}
You and $I$ enter into the following contract: I promise to pay you $\$ 6,000$ on the 25 th of each month for the next five years. You prumise to pay me $\$ 1,000 \times X$ on the 25 th of each month for the next five years. $X$ is equal to the "Ask yield" on U.S. Treasury Bonds maturing in five years... We have what appears to be a relatively simple contract, with reciprocal consideration, mulual benefits, and an insulating effect with respect to sudden moves in interest rates. Beneath this facade of benign simplicity, however, beats the heart of a monster.... For the agreement between us is no ordinary contract: it is a derivative.
\end{abstract}

The "facade of benign simplicity" with respect to derivative contracts emerges because a derivative instrument is an executory contract. On the face of it, one would think that such agreements should be interpreted in accordance with the well-understood principles of contract law. The monumental financial repercussions arising out of the use of derivative instruments, however, is what renders them "monstrous," and it is this monster that has caused courts to struggle with the principles of interpretation to be employed in the context of default, termination and the calculation of damages.

1 In fact, such practice is not limited to oil and gas companies. $\wedge$ survey conducted by the International Swaps and Derivatives Association (ISDA) discloses that 92 percent of the world's 500 largest companies use derivative instruments to manage and liedge risks. See ISDA News Release 19 April 2003), online: ISDA <www.isda.org/press/surveynewsrelease030903.html>.

: A useful overview is contained in Mark R. Smith, "Basic Derivatives for the Oil and Gas Company" (2001) 39 Alta. L. Rev. 152. The Alberta Court of Appeal similarly provides a useful overview in the context of gas contracts in Blite Range Resource Corp. (Re) (2000), 87 Alta. L.R. (3d) 329 [Blue Range].

3 William K. Maready, Jr., "Regulating for Disaster: Federal Attempts to Control the Derivatives Market" (1996) 31 Wake Forest L. Rev. 885 at 885 
A more topical prelude to the issues surrounding default, termination and damages is the description of forward commodity contracts employed by the Court in Blue Range, ${ }^{4}$ where Fruman J.A., speaking for the Court, states:

"[F]orward commodity contracts" ... according to text writers ... are merely "contract[s] to buy or sell an asset at a certain price on a future date."

These instruments are all part of the global derivatives market. Derivative products are investment tools whose value depends on, or is derived from, the performance of some underlying asset such as stocks, bonds, commodities, currencies or indices... Forward commodity contracts and other derivatives have a financial value that can readily be calculated; they are commercial hedging contracts that can be used to manage various types of risk, including changes in commodity prices, exchange rates, interest rates and market risks. ${ }^{5}$

There is a myriad of forms that a derivative contract may take. Generally speaking, counter-parties enter into a master agreement that serves to govern the overall relationship between the parties. The master agreements, however, generally do not contain any obligation to purchase or sell the underlying commodity. The Alberta Court of Appeal noted in Nesi Energy Marketing Canada Lid. (Trustee of) v. NGL Supply (Gas):

\footnotetext{
The master agreements merely provide a framework for future contractual relations. They do not specify what quantities of gas are te be bought or sold, the price, or the due dates of any obligations. Lacking the essential components of a contract, they merely anticipate the formation of future contracts. At most, the master agreements are agreements to enter into future contracts, elaborating some of the terms and conditions to be incorporated into these future contracts. The master agreements provided a mechanism whereby the [counterparties] could contract, from time to time, without renegotiating and revisiting basic terms alteady addressed in the master agreements. ${ }^{\circ}$
}

Individual agreements, often done by side letter incorporating the terms of the master agreement, are entered into to deal with individual transactions for matters like forward contracts, swaps, collars, ceilings, floors and options. That being said, it is difficult to generalize with respect to the various master agreements utilized by industry participants. The ISDA produces a standard form of master agreement (ISDA Agreement) that has been used by some industry players over the years. The ISDA Agreement, ${ }^{7}$ however, has given way to agreements developed by some of the market makers trading in the oil and gas derivative market. In any event, the hallmark of most master agreements, whatever form they may take, is that a non-defaulting counter-party is afforded the ability to terminate the master agreement and the individual transactions created thereunder upon a default occurring. 


\section{Termination and Netting-Out Provisions}

\section{A. Termination and Netting-Out Generally}

Arguably, the most critical feature of a master agreement is the provision that permits a party to terminate all transactions upon default or other termination event, to calculate the value of all transactions as of the termination date and to net the positive and negative values. It is of utmost importance to the parties to the agreement that termination and close-out netting provisions are enforceable against the other party. Parties accessing capital markets are not willing to assume the risk that such provisions may not be fully enforceable. Given the increasing ability of firms to conduct business almost anywhere, jurisdictions that do not give regard to contractual provisions relating to termination and netting out rights will be placed at a serious disadvantage. ${ }^{8}$

In Canada, there has been a complete acceptance of the prevalence and importance of derivative instruments. Justice Farley of the Ontario Court (General Division) articulated the increasing prominence of financial derivatives in the world of commerce in Confederation Treasury Services Ltd. v. Hees International Bancorp:

Derivative contracts have become increasingly popular as a legitimate method of managing risk. It would seem as a matter of public policy that such a valuable tool which has become a key fundamental for the interlocking financial activities of virtually every major financial and many major non-financial corporations in Canada (and having international links) should not be dealt with in such a manner as to seriously affect its efficiency.

\section{B. INSOLVENCY OF ONE COUNTER-PARTY}

Events of default include a host of pre-negotiated and specified items. Typically, however, master agreements contain provisions that permit the non-defaulting party to terminate upon the counter-party instituting or having instituted against it formal insolvency proceedings. In Canada, this usually involves proceedings commenced under the Companies' Creditors Arrangement $A t^{10}$ or proceedings involving a formal proposal or liquidation under the Bankruptcy and Insolvency Act."

ISDA recognizes this critical feature in relation to derivative instruments and has published the 2002 Model Netting $A c t,{ }^{12}$ which encourages jurisdictions that do not have netting legislation to take steps to ensure that netting legislation is implemented. The ISDA model legislation sets out a non-exhaustive list of defined qualified financial contracts ${ }^{13}$ that includes: "energy derivatives, such as ... oil derivatives ... and gas derivatives."14 Qualified financial contracts that contain netting provisions are to be govemed by the general rule prescribed by the model legislation in $\mathrm{s.} 4$ as follows:

Grottenthaler \& Henderson. The Law of Financial Derivalives in Canada (Toronto: Carswell, 1999) at 5.3.

(1997), 45 C.B.R. (3d) 204 al 231.

R.S.C. 1985, c. C-36 [CCAA]

R.S.C. 1985, c. B-3 $[B L A]$.

Online: ISDA <www.isda.org/docproj/netact.pds.

Ibid. s. I.

lbid. 
The provisions of a netting agreement will be enforceable in accordance with their terms against the insolvent party and, where applicable, against a guarantor or other person providing security for the insolvent party and will not be stayed, avoided or otherwise limited by any action of the liquidator, by any other provision of law relating to bankruptcy, reorganization, composition with creditors, receivership, conservatorship or any other insolvency proceeding the insolvent party may be subject to or by any other provision of law that may be applicable to the insolvent party, subject to the conditions contained in the applicable netting agreement. ${ }^{15}$

A news release issued by ISDA heralding the implementation of netting legislation by Hungary contains a succinct statement of the perceived benefit of such provisions:

\begin{abstract}
Close-aut netting of derivative transactions, which reduces credit risk arising from [over the counler] derivatives by allowing counterparties to net their obligations, pursuant to a netting agreement is a legal and enforceable mechanism for calculating a claim against an insolvent counterparty under the [Hungarian netting legislation]. The provision prohibits the insolvency officer from any attempt of "cherry-picking" between inthe-money and out-of-the-money transactions. The [Hungarian netting legislation] also makes it clear that close-out netting cannot be tseated by any person as an agreement intended to defraud other creditors and decrease the assets of the debtor. ${ }^{16}$
\end{abstract}

Insolvent counterparties with debt in excess of five million dollars typically attempt to restructure, at least in the first instance, under the rubric of the CCAA. Section 11 of the $C C A A$ affords the court the ability to impose a broad stay of proceedings against creditors and counter-parties with respect to the exercise of contractual rights of termination. Prior to 1992, Canada did not have netting provisions in its insolvency legislation. In 1992, the BlA was amended ${ }^{17}$ to make provisions for derivative instruments in what are known as the "eligible financial contracts" provisions. The CCAA was similarly amended in 1997. ${ }^{18}$ The amendment to the $C C A A$ provides that "no order may be made under [the $C C A A$ ] staying or restraining the exercise of any right to terminate, amend or claim any accelerated payment under an eligible financial contract."19 The definition of eligible financial contract reads, in part:

II.I(1) Jn this section, "eligible financial contract" means

(h) a spot, future, forward or otter commodity contract.

(i) any derivative, combination or option in respect of, or agreement similar to, an agreement or

(j) contract referred to in paragraphs (a) to (i),

(k) any master agreement in respect of any agreement or contract referred to in paragraphs (a) to (j). ${ }^{20}$

Until the eligible financial contract amendments became law, a court had discretion under the CCAA to interfere with the ability of the solvent counter-party to elect to terminate

Ibid.

ISDA Welcomes Implementation of Hungarian Netting Legislation, ISDA News Release. (4 January 2002), online: ISDA < $\mathrm{mnw}$.isda.org/press/press010402.hıml>.

S.C. 1992, c. 27 , s. 30.

S.C. 1997 , c. 12 , s. 124.

Supra note 10, s. I1(2).

Ibid., s. 11. 
agreements with an insolvent counter-party and to net out positions. The effect of the eligible financial contract amendments permits the non-defaulting, solvent counter-party to exercise the rights afforded to it under its agreement, notwithstanding the resort to insolvency protection by the defaulting counter-party.

The eligible financial contract amendments, as they deal with the prohibition against staying counter-party remedies with respect to eligible financial contracts, are clear and unambiguous. Prior to Blue Range $e^{21}$ there was confusion with respect to whether agreements in the nature of master agreements generally fit within the rubric of eligible financial contracts. The Court's decision in that case established that purchase and sale agreements in relation to oil and gas, which extend into the future and whether physically settled or not, are in fact eligible financial contracts. In addition, provisions in agreements that permit the solvent counter-party to terminate and net-out positions, whether in or out of the money, are effective even if the insolvent counter-party is operating under court protection and a general stay of proceedings. Accordingly, provided an agreement (such as a master agreement) is in place which permits termination and netting-out upon the occurrence of a pre-defined insolvency event by one counter-party, then the general stay of proceedings imposed in formal insolvency proceedings will not disentitle the non-defaulting counter-party from exercising such rights.

\section{NON-INSOLVENCY SCENARIOS}

Master agreements typically set out additional items of default beyond insolvency defaults. Another such item of default one may find in a master agreement is the occurrence of what is known as a material adverse change (MAC). The only limit on what will constitute a MAC is the pen of the draftsperson who is charged with the responsibility of drafting a master agreement. In Enron Canada Corp. (Re), ${ }^{22}$ the example of a MAC cited was the diminishment in the credit-worthiness of a guarantor of the obligations of the counter-party under a master agreement.

Specific provisions with respect to the calculation of termination damages differ in each of the various master agreements. Notwithstanding this fact, there are certain commonalities that arise in most of those agreements. Master agreements typically provide that on the termination date, the parties are obligated to make a settlement payment that reflects the thencurrent value of the terminated agreements. Settlement utilizing a two-way method involves the non-defaulting party calculating the net amount of its gains and losses on termination. If the net amount results in a net gain to the non-defaulting party, then the non-defaulting party has a claim against the defaulting party for the amount of such gain. If the net amount results in a net gain to the defaulting party, then the non-defaulting party is obliged to pay such amount to the defaulting party.

Settlement utilizing, sometimes referred to as a one-way payment or limited two-way payment, involves the non-defaulting party calculating the net amount of its gains and losses on termination. As in the case of the two-way method, if the net amount results in a net gain

$\therefore$ (2001). 210 A.R. 386 (Q.B.) [Enron] 
to the non-defaulting party, then the non-defaulting party has a claim against the defaulting party for the amount of such gain. If, however, the calculation results in a net loss to the nondefaulting party, then it is entitled to walk away without making any payment to the defaulting party.

\section{Collateral Security}

Enforceable termination and netting provisions are merely one method to minimize the risk in relation to derivative agreements. Often, a non-defaulting party will sustain or incur significant damages upon the termination of a derivative contract. In those instances where a particular agreement is "in the money," the non-defaulting party will often be forced to go to the market following termination and enter into an agreement at a greater cost than the terminated agreement. If the defaulting counter-party is insolvent or otherwise unable to pay the damages associated with early termination, the non-defaulting party will suffer the loss associated with the early termination of the agreement. Another way to minimize the risk involved in derivative contracts is to obtain collateral security to secure the performance of the obligations arising under the agreements.

Collateral security can be an effective tool to minimize risk by diminishing credit exposure. The effect of securing the obligations arising under a derivative transaction is that the credit risk of the party to the secured transaction is substituted for the risk of the counterparty. The nature of collateral that can be utilized is not limited. Common forms of collateral include third party guarantees, letters of credit and the pledging of cash or marketable securities. The latter form of collateral security requires an analysis of the requirements imposed by legislation governing secured transactions to ensure that the security is valid and enforceable against third parties, including bankruptcy representatives (such as a trustee in bankruptcy) and other creditors of the counter-party in question.

\section{A. Thiro Party Guarantees}

Third party guarantees, strictly speaking, do not give rise to a secured claim by the beneficiary of such guarantee. A third party guarantee (which in Canada is often made by an American parent with respect to the obligations of its Canadian subsidiary) can nevertheless be an attractive risk-management tool where the risk profile of the counter-party does not support the exposure in the transaction. Often, the subsidiary has no significant assets other than the derivative instruments in which it is trading. The guarantor, however, is often possessed of significant assets and the covenant provided by such guarantor may, from a riskmanagement perspective, be adequate to cover the risk profile.

\section{B. LETTERS OF CREDIT}

Letters of credit are another effective instrument used to minimize risk. Letters of credit are typically issued by financial institutions. They are governed by the terms of the credit and usually provide that the issuing financial institution will honour demands for payment by a counter-party upon compliance with the conditions specified in the credit. Ideally, the letter of credit will also contain few conditions and will provide for payment by the issuer upon presentment by the beneficiary of the letter, together with a certified statement that the condition for payment stipulated has occurred. 
Letters of credit may be either revocable upon the election of the issuer or irrevocable. From the beneficiary's perspective, if the letter of credit is revocable, then one must be mindful of the length of notice the issuer must provide prior to the revocation becoming effective. The master agreement should correspondingly require that replacement security, in the same form as the letter of credit or in such other form as may be acceptable to the beneficiary, be provided prior to the expiration of the letter of credit. Even if a letter of credit is irrevocable, however, such instruments normally expire on a specified date and care must be taken to ensure that arrangements are made either to cover the risk or to bring it within acceptable parameters prior to the expiration of the letter of credit.

\section{Security OVer Cash and Marketable Securities}

Security over cash, government treasury obligations and agency issues are other effective methods to manage risk. Under such agreements, the debtor counter-party typically pledges cash or other highly liquid securities as security for its obligations. Upon default and nonpayment of amounts owing to the creditor counter-party, the security interest in the pledged collateral can be realized upon by the creditor counter-party. In order for the security interest to be effective as against third parties, it must be perfected in accordance with the provisions of the Personal Property Security Act. ${ }^{23}$ Section 19 reads:

A security interest is perfecled when

(a) it has attached, and

(b) all steps required for perfection under this Act have been completed, regardless of the order of occurrence.

Attachment is the process that brings the security interest into being and is the point at which the secured party acquires an in rem interest in the collateral. Attachment is governed by $s .12$ which provides, in part:

12(1) A security interest, including a security interest in the nature of a floating charge, attaches when

(a) value is given,

(b) the debtor has rights in the collateral, and

(c) except for the purpose of enforcing rights between the parties to the security agreement, the security interest becomes enforceable within the meaning of section 10.

Section 10 deals with the pre-conditions to ensure that a security interest is enforceable as against third parties. The section sets out two essential mechanisms for enforceability in this regard: possession of the collateral by the secured party; or the existence of a signed security agreement which describes the collateral, where applicable, as "money," "securities," or "instruments."

Care needs to be taken, however, with respect to the perfection and priority of security over cash or marketable securities. Possession of collateral of this nature is a difficult, if not impossible, circumstance. Accordingly, perfection of the secured counter-party's interest will need to be realized through the registration of a financing statement with the personal 
property registry. Registration will ensure that such securities are subject to the priorities mandated by the PPSA and that they take priority over subsequent secured interests, ${ }^{24}$ a subsequently-appointed trustee in bankruptcy, ${ }^{25}$ or a subsequent unsecured enforcement creditor. $^{26}$

\section{IS THERE A REQUIREMENT TO PROVIDE \\ REASONABLE NOTICE OF TERMINATION?}

\section{A. Insolvency Proceedings}

If the nature of default is one of formal insolvency proceedings with respect to the defaulting counter-party, then by its very nature this type of default will not require advance notification of termination provided that the master agreement makes provision for immediate termination. The ISDA Agreement, for example, must permit the parties to elect automatic early termination if the nature of the default is bankruptcy default. Automatic early termination stipulates that "early termination ... in respect of all of outstanding transactions will occur immediately [upon the event of a bankruptcy default]."27

\section{B. Non-InSOLVENCY PROCEEDINGS}

In those instances where there is a non-insolvency default, however, the question arises as to whether the non-defaulting party needs to provide notification of its intention to rely upon default provisions in the master agreement beyond any time prescribed to cure any such non-insolvency default specified therein.

The proceedings involving Enron Canada Corporation (Enron Canada), ${ }^{28}$ following the demise of its parent Enron Corporation (Enron Corp.), gave rise to arguments in this regard. Enron Canada entered into a number of master agreements with various counter-parties. Under many of those agreements, the obligations of Enron Canada were guaranteed by Enron Corp. Enron Canada claimed to be solvent but a number of its counter-parties relied on provisions which mandated that the decrease of its parent's credit-worthiness constituted a MAC under the master agreement, permitting the non-defaulting and notifying counter-party to terminate the same.

A number of the non-defaulting counter-parties commenced actions against Enron Canada for amounts alleged to be due to them as a result of Enron Canada's alleged defaults under the various master agreements. Enron Canada defended the actions and counter-claimed alleging, inter alia, that the terminations were wrongful. ${ }^{29}$ One argument that Enron Canada raised in its pleadings was that it was entitled to receive reasonable advance notice of the non-defaulting counter-parties' intention to terminate the master agreement.

Ibid., s. 35.

Ibid., s. 20(a)(i).

Civil Enforcement Act, R.S.A. 2000, c. C-15, s. 35.

Master Agreement, supra note 7 at 3-5.

Enron, supra note 22.

Baylex Energy Lid. v. Enron Canada (2002), 329 A.R. 302 (Q.B.) 
Canadian courts recognize the existence of a duty placed upon a creditor to give a debtor reasonable notice to comply with a demand for payment. The seminal case of Ronald Elwyn Lister Lid. v. Dunlop Canada Lid. ${ }^{30}$ involved a fact situation where the debtor alleged that the creditor, who held security over the assets and an undertaking of the debtor by way of debenture security, acted precipitously by appointing a receiver and manager. In delivering judgment for the Court, Estey J. stated that

[1] he rule has long been enunciated in Mrassey v. Sladen (1868), L.R. 4 Ex.13 at p. 19: that the debtor must be given "some notice on which he might reasonably expect to be able to act." The application of this simple proposition will depend upon all the facts and circumstances in each case. Failure to give such reasonable notice places the debtor under economic, but nonetheless real duress, often as real as physical duress to the person, and no doubt explains the eagerness of the courts to construe debt-evidencing or creating documents as including in all cases the requirement of reasonable notice for payment. ${ }^{31}$

There have been a number of decisions following Lister that have amplified the obligation of a creditor to provide reasonable notice of its intention to demand repayment of a loan and enforce security. It does not follow, however, that such a principle carries through to contractual relations between parties to a derivative instrument. In the lender-borrower context, there often exists a relative inequality in bargaining power. Moreover, the magnitude of damage that can be done to the lender during a demand period is relatively less significant than the amount of damage that can accrue to a counter-party to a derivative contract if the counter-party is required to provide reasonable notice beyond that which is stipulated in the master agreement. Furthermore, in the traditional secured lender-debtor relationship, there are conservatory measures (for example, the appointment of an interim receiver) that a secured lender can take to preserve its position until it is in a position to take enforcement proceedings.

A non-defaulting party who is "in the money" with respect to a particular transaction, practically speaking, has no such conservatory measures available to it. The passage of mere hours can potentially bring with it millions of dollars of losses. Accordingly, the "simple proposition" enunciated by the Court in Lister should not extend to import any additional notice requirement on the non-defaulting party other than that which is set out in the applicable master agreement.

\section{Good Faiti Requirement}

Developments in Canadian contract law over the past decade and a half no longer make it necessary to enquire whether there is a duty for a party to bargain in good faith. Pronouncements of the Supreme Court of Canada from the early 1990s make it clear that, in the context of contractual negotiations, the good faith doctrine is pervasive. ${ }^{32}$ However, whether such a duty exists in the context of contractual performance is less clear. 
In 1989, the Supreme Court of Canada considered the broad issue, albeit in the context of contractual negotiations, in LAC Minerals Ltd. v. International Corona Resources Ltd. After categorizing the relationship that arose between the parties as being fiduciary in nature, La Forest J. stated: "[ $t$ ]he institution of bargaining in good faith is one that is worthy of legal protection in those circumstances where that protection accords with the expectations of the parties."33

The next year, in its decision in Houle v. Canadian National Bank, ${ }^{34}$ the Supreme Court of Canada solidly affirmed the principle while considering the applicability of the doctrine of abuse of rights in the context of Quebec civil law. Justice L'Heureux-Dubé, writing for the Court, stated:

\begin{abstract}
But more fundamentally, the doctrine of abuse of contractual rights today serves the important social as well as economic function of a necessary control over the exercise of contractual rights. While the doctrine may represent a departure from the absolutist approach of previous decades, consecrated in the well-known maxim "la volonte des partic fait loi" (the intent of the parties is the governing factor), it inserts itself into today's Irend towards a just and fair approach to rights and obligations... Such uncertainty which the doctrine of abuse of rights may bring to contractual relationships, besides being worth that price, may be counterbalanced by the presumption of good faith which remains basic in contractual relationships. ${ }^{\text {3s }}$
\end{abstract}

Infused in the Supreme Court's decisions is the notion that the parties' expectations are relevant in assessing to what degree the duty of good faith will be imposed and the corresponding applicability of the doctrine.

In 1991, the Supreme Court of Nova Scotia recognised a general duty of good faith in contractual performance over and above the specific wording of a contract. In Gateway Realty Ltd. v. Arton Holdings Ltd. ${ }^{36}$ Gateway Realty Lid. (Gateway) owned a shopping centre, a significant portion of which had been leased to Zellers. Arton Holdings Ltd. (Arton) was the owner of a rival shopping centre that convinced Zellers to move to its shopping mall and assign to it the balance of Zellers' 17 year lease with Gateway. Pursuant to a subsequent agreement between Gateway and Arton, the latter agreed to use its "best efforts" to lease the space formerly occupied by Zellers.

Justice Kelly found that not only had Arton failed to use its "best efforts," but that it was in breach of the more general obligation to act in good faith:

The law requires that parties to a contract exercise their rights under that agreement honestly, fairly and in good faith. The standard is breached when a party aets in a bad faith manner in the performance of its rights and obligations under the contract. "Good faith" conduct is the guide to the manner in which the parties should pursue their mutual contractual objectives. Such conduct is breached when a party acts in "bad faith" - a conduct that is contrary to community standards of honesty, reasonableness or fairness. ${ }^{37}$

Jbid. at para. 65 .

(1991), 106 N.S.R. (2d) 180 (S.C. (T.D.)), affd (1992), 112 N.S.R. (2d) 180 (S.C. (A.D.)).

lbid. al para. 38. 
The Court noted that though the parties were granted certain rights under the contract, those rights were subject to a general duty to act in a manner that was neither arbitrary nor unreasonable. In discussing the good faith requirement as it relates to the discharge of contractual duties, Professor O'Byrne stated that "as a starting point, every contract contains a good faith obligation. What the parties must do to meet this obligation will depend on the surrounding circumstances, including the norms governing the commercial sector in question." 38

The evolution of good faith in the discharge of contractual obligations was also considered by the Alberta Court of Appeal in Mesa Operating Lid. v. Amoco Canada Resources Lid. Justice Kerans, speaking for the Court, adopted the test set out by the trial judge who stated that

[i]n Canada, the test ... does not include the need for the plaintiff to show that the defendant intentionally acted in bad faith.... the common law duty to perform in good faith is breached when a party acts in bad faith, that is, when a party acts in a manner that substantially nullifies the contractual objectives or causes significant harm to the other, contrary to the original purposes or expectations of the parties. ${ }^{30}$

However, Kerans J.A. expressly refused to identify this test as one of good faith; rather, he held that the obligation arose out of the contract and the parties' reasonable expectations. He found that, "[i]n other words, the duty arises as a matter of interpretation of the agreement. The source of the rule is not the law but the parties. I worry that the term 'good faith' in this case might blur that distinction." 40 This has led at least some commentators to argue that the test formerly labelled "good faith" is now available for use under the normal rules of contractual interpretation."1

Accordingly, it is clear that there is a duty to bargain in good faith and an arguable duty to undertake one's contractual obligations honestly and fairly. However, the more vexing question is under what circumstances will one be construed to be acting in bad faith if one counter-party to a derivative contract exercises termination and netting-out rights following default by another counter-party. Clearly, the norms and expectations of players living in the commercial world of oil and gas derivatives would have to be taken into consideration. In view of such consideration, it would seem exceptional for a court to find that a counter-party in a derivative transaction was acting in bad faith following default, given the potential for damages to accrue rapidly to the non-defaulting party.

That is not to say that circumstances might exist which would give rise to a successful claim that the non-defaulting counter-party has acted in bad faith. Given the vested nature of the rights held by counter-parties to derivative contracts, however, the evidentiary standard required to demonstrate that a party exercised discretionary contractual rights in bad faith would be very high indeed. 


\section{Walk-Away Provigions - Liquidated Damages or Penalties?}

Parties to a contract are competent to agree with respect to what will be payable as damages in the event of a breach. In the case of a one-way payment or limited two-way payment provision, the parties agree beforehand that in the event of a breach the damages payable to a non-defaulting counter-party who is "out of the money" will be to the extent of such position. Consideration needs to be given as to whether such a provision constitutes a genuine pre-estimate of damages or a penalty. In the former situation, the walk-away provision will be enforceable and, if the net position of the non-defaulting party is such that it owes the defaulting party money, there will be no further liability on the part of the nondefaulting party. In the latter situation, however, equity may intervene to disentitle the nondefaulting party from relying upon its negotiated contractual rights.

Penalty clauses are intended to discourage parties from breaching an agreement by creating a disincentive for non-performance greater than what the innocent party otherwise would be entitled to receive by way of an assessment of damages flowing from the breach.

In Digger Excavating (1983) Lid. v. Bowlen," the Alberta Court of Appeal succinctly summarized the state of the law as it relates to the distinction between a genuine pre-estimate of damages and a penalty. The Court cited with approval the leading common law decision of Dunlop Pneumatic Tyre v. New Garage and Motor Co. Lid. as follows:

The leading decision on penalties is Dumlop Pnetumatic Tyre Co. v. Nell Garage and Motor Co. L.td. [1915]

A.C. 79 (H.I.). In that case, the Ilouse of Lords held that the court will review the circumstances at the time of making the contract to determine whether the payment was intended as liquidated damages, a genuine preestimate of the loss, or rather a penal provision ... in terrorem of the offending party: the characterization by the parties is not determinative. ${ }^{43}$

In terrorem clauses have been characterized as security to the non-defaulting party that the contract will be performed. A leading United Kingdom treatise on contract law states that

a sum of this nature is called a penalty, and it has long been subject to equitable jurisdiction. Courts of equity have laken the view that the promisec is sufficiently compensated by being indemnified for his actual loss, and that he acts unconscionably if he demands a sum. which though certainly fixed by agreement. may well be disproportionate to the injury. ${ }^{44}$

If the benefit derived from the non-defaulting party is grossly disproportionate to the damages suffered by it, then it is possible that the provision in question can be construed as a penalty. To avoid categorization as a penalty, the parties need to attempt to provide for an assessment of damages rather than an imposition of a penalty. When damages must be capable of a quick calculation, such as in a trading scenario where market participants need to know their rights and liabilities, a powerful argument exists to honour a liquidated damage clause. 
There is a paucity of case law considering the import of this issue. In Drexel Burnham Lambert Products v. Midland Bank PLC, th the argument that a limited two-way provision constituted a penalty was rejected. Drexel Burnham Lambert Products Corporation (Drexel Products) entered into a swap with Midland Bank PLC (Midland) which contained a limited two-way payment provision. Drexel Products assigned its interest under the swap to Drexel Burnham Lambert Group, which subsequently filed a Chapter 11 petition under the United States Bankruptcy Code. ${ }^{\text {to }}$ The District Court was called upon to adjudicate whether the limited two-way provision was enforceable. The Court held that Drexel Products was prevented from asserting a claim against Midland irrespective of whether Midland was "out of the money." The Court held:

\begin{abstract}
The so-called "Limited Two-Way Payments Clause" set forth in the Swap Agreement between Drexel GSI and Midland constitutes a valid liquidated damages clause and is, therclore, enforceable in accordance with its terms. The Limited Two-Way Payments Clause in the Swap Agreement between Drexel GSI and Midland is not unconscionable or contrary to public policy as the amount liquidated bears a reasonable relationship to the probable loss, and the amount of actual loss is incapable or diflicult of precise estimation at the time the contract is entered into. The Limited Two-Way Payments Clause in the Agreement between Drexel GSl and Midland is not void or contrary to public policy. Requiring DrexeI GSI to forego an unrealized investment gain is neither a penalty, a forfeiture nor an unjust enrichment. ${ }^{47}$
\end{abstract}

The Court did not specify the magnitude of Midland's "out of the money" position. While at first blush one might be inclined to surmise that the size of the "out of the money" position might influence a court's discretion in determining whether such a clause is a penalty, it is useful to recall that the relevant time for ascertaining whether a provision is a genuine preestimate of liquidated damages or a penalty is at the time that the parties enter into the agreement. Accordingly, notwithstanding the potential punitive nature of a limited two-way payment provision, a compelling argument can be made that, given the nature of the underlying transactions and financial risk to which the parties are exposed, effect ought to be given to such clauses and parties should be entitled to enter into individual transactions secure in the knowledge that they will be entitled to rely upon their negotiated contractual rights.

\title{
VIII. ConClusion
}

In recent years, Parliament and Alberta courts have recognized the importance of giving effect to termination and netting-out rights contained in derivative contracts in relation to insolvency events. The recognition stems from an understanding that the flow of capital is important to sustain and develop core businesses such as oil and gas. Absent a clear intention to give effect to such provisions outside of formal insolvency proceedings, the risk exists that industry players will seek jurisdictions to do business in which their ability to rely upon contractual terms fundamental to the business and underlying risk is not in dispute. 